\title{
Shear Bond Strength of Ceramic Bonded to Different Core Materials and Their Pattern of Faillure: An In Vitro Study
}

\author{
Shilpa $\mathrm{P}^{1}$, Narendra $\mathrm{R}^{1}$, Sesha Reddy ${ }^{1}$, Sashideepth Reddy ${ }^{1}$ \\ 1. Prosthodontics, Government Dental College and Hospital, Kadapa, IND
}

Corresponding author: Shilpa P, shilpagdckadapa@gmail.com

\begin{abstract}
Introduction

In metal-ceramic restoration, most of the bond failures between the ceramic layer and the metal coping is the chipping of the ceramic layer, thus exposing the metal surface, which compromises the aesthetics. Hence, this leads to the introduction of zirconia-based restorations in dentistry. However, even zirconium coping has the common complication of delamination or porcelain chipping from the zirconium core. Hence, the shear bond strength between the commonly used core materials and ceramic requires investigation to facilitate the materials in clinical use for longevity. Therefore, this study was conducted to compare the shear bond strength between different core materials and ceramic layering to find out the best core material for ceramic bonding.
\end{abstract}

\section{Materials and methods}

A total number of 45 samples were made as per ISO standardization (base $5 \mathrm{~mm}$ diameter and $1 \mathrm{~mm}$ thickness, step with $4 \mathrm{~mm}$ diameter and $4 \mathrm{~mm}$ in length). These samples were divided into three groups, Group A: Nickel-chromium, Group B: Cobalt-chromium, and Group C: Zirconium. Ceramic layering was layered on the top surface of each sample until an ideal height of $4 \mathrm{~mm}$ was obtained, and it was subjected to shear bond strength using a universal testing machine with a 50-KN load cell. This was followed by analyzing the nature of the fracture pattern using scanning electron microscopy (SEM).

\section{Results}

There were no significant differences found for the shear bond strength among group A and group B. The zirconium (group C), however, had significantly lower values than both group A and group B. The microscopic examination also revealed that the failure between the coping and the ceramic layer primarily occurred near the interface with the residual veneering porcelain remaining on the core.

Received 11/12/2019

Review began 11/24/2019 Review ended 11/24/2019 Published 11/26/2019

๑) Copyright 2019

$P$ et al. This is an open access article distributed under the terms of the Creative Commons Attribution License CC-BY 3.0., which permits unrestricted use, distribution, and reproduction in any medium, provided the original author and source are credited.

\section{Conclusions}

It was found that the shear bond strength of the metal-ceramic group is better than the zirconium ceramic group, however, the fracture between the copings and the ceramic layering is found to be similar for both adhesive and cohesive failure.

Categories: Miscellaneous, Dentistry

Keywords: bond strength, ceramic bonded core

\section{Introduction}

Porcelain fused to metal systems has been extensively used in fixed partial denture (FPD) for more than 40 years and still represents the gold standard. Porcelain-fused metal systems have the combined effect of the fracture resistance of the metal substructure and the esthetics property of porcelain [1-2]. Until the early 1970s, base metals were used for removable prostheses and gold-based alloys with more than 70 weight percentage (wt. \%) of pure gold were used for fixed dental prostheses. For the same volume, base metal alloys weigh less than gold, enabling the production of light and thin prostheses [3-5]. Nickel-chromium (Ni-Cr), titanium (Ti), and cobalt-chromium (Co-Cr) alloys are typically used in base metal-ceramic restoration [6]. De Melo et al. [7] investigated the bond strengths of dental ceramic to Ni-Cr alloy and $\mathrm{Co}-\mathrm{Cr}$ alloy by using a shear force test and found no significant differences between the two alloys. Joias et al. [8] found that the bond strength of ceramic to a Co-Cr alloy depends on the alloy composition. In clinical scenarios, shear bond strength greater than $25 \mathrm{MPa}$ is considered acceptable [9]. Even if metal-ceramic restorations are well designed, they are susceptible to porcelain fractures occurring inside the substrate or at the metal-ceramic interface.

Hence, the introduction of partially stabilized yttria tetragonal zirconia polycrystals demonstrates the 


\section{Cureus}

transformation toughening mechanism, with a flexural strength of 900 - $1200 \mathrm{MPa}$ and a fracture toughness of $9-10 \mathrm{MPa} \bullet \mathrm{m} 1 / 2$. Due to its mechanical properties, zirconia has enough strength to withstand high occlusal stress [10-11]. However, delamination or a minor chip-off fracture of veneering porcelain is the frequent reason for the failures of zirconia FPDs. Therefore, the bond between the core and veneer or within the veneer material itself is one of the weaknesses in layered zirconia-based restorations and plays a significant role in their long-term success [12-15]. Thus, the shear bond strength between the commonly used core materials and ceramic requires investigation to facilitate the materials in clinical use. While Deepak et al. examined the shear bond strength of ceramic bonded to two base metal alloys that are surface treated, [16] this present study included two base metal alloys along with zirconium without any surface treatment.

\section{Materials And Methods}

Three core materials, Ni-Cr (group A) and Co-Cr alloys (Group B) (Ceralloy NI, Dentalloy International Private Ltd, India.), and zirconium (Group C) (NexxZr-T- Sagemax, Bioceramics, Sweden) were used for the fabrication of 45 samples, with each group having 15 samples. The samples were fabricated according to the International Organization for Standardization (ISO). The specification of the samples is as follows: the base is $5 \mathrm{~mm}$ in diameter and $1 \mathrm{~mm}$ in thickness and the step is $4 \mathrm{~mm}$ in diameter and $4 \mathrm{~mm}$ in length [16-17] (Figure 1). For all the specimens, degassing was done to form the oxide layer, which helps in increasing the ceramic bonding. According to the manufacturer's instruction, all the 45 samples were first coated with two thin layers of opaque paste on the $4 \mathrm{~mm}$ diameter surface, and then the first firing was done in the ceramic furnace, followed by the application of dentin to obtain $4 \mathrm{~mm}$ height [16]. These samples, with a $\mathrm{Ni}-\mathrm{Cr}$, Co$\mathrm{Cr}$, and Zirconium core bonded to ceramic (Figure 2), were inserted into an acrylic block (12 mm $\times 12 \mathrm{~mm} \times$ $12 \mathrm{~mm}$ ) to the level just below the junction of the core material and ceramic (Figure 3). These samples were then subjected to shear bond testing using a Universal Testing Machine (Model 1500, Dak series; Dak System Inc., Mumbai, India) with a 50-KN load cell and a crosshead speed of $1.0 \mathrm{~mm} / \mathrm{min}$ and the tool placed $1 \mathrm{~mm}$ above the junction until fracture occurred. Force was applied to the sample so that the shear load was exerted adjacent to the bonding interface (Figure 4). Load deflection curves and ultimate load to failure were recorded automatically and displayed by the software in the testing machine. The shear bond test was calculated as follows:

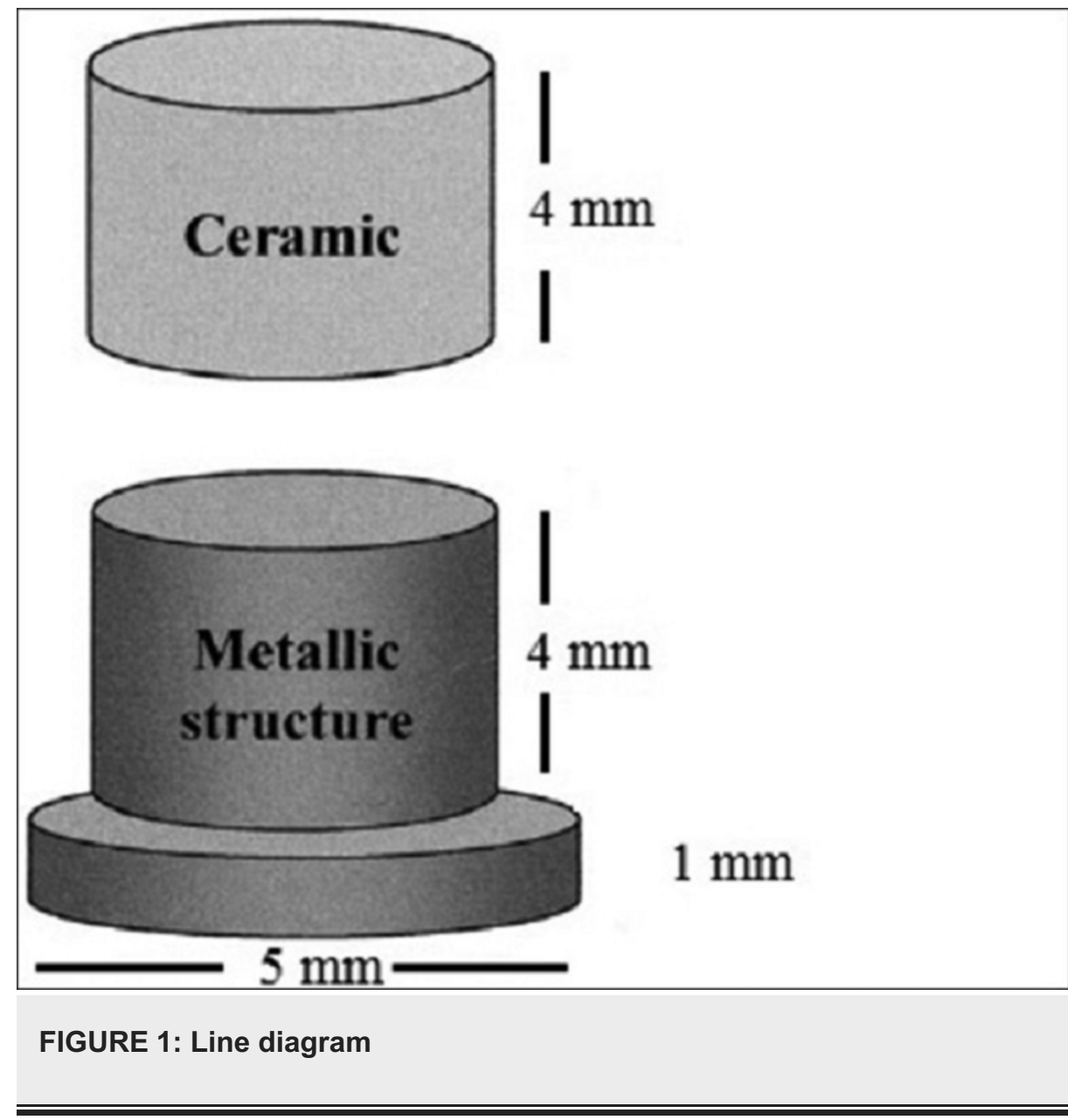




\section{Cureus}

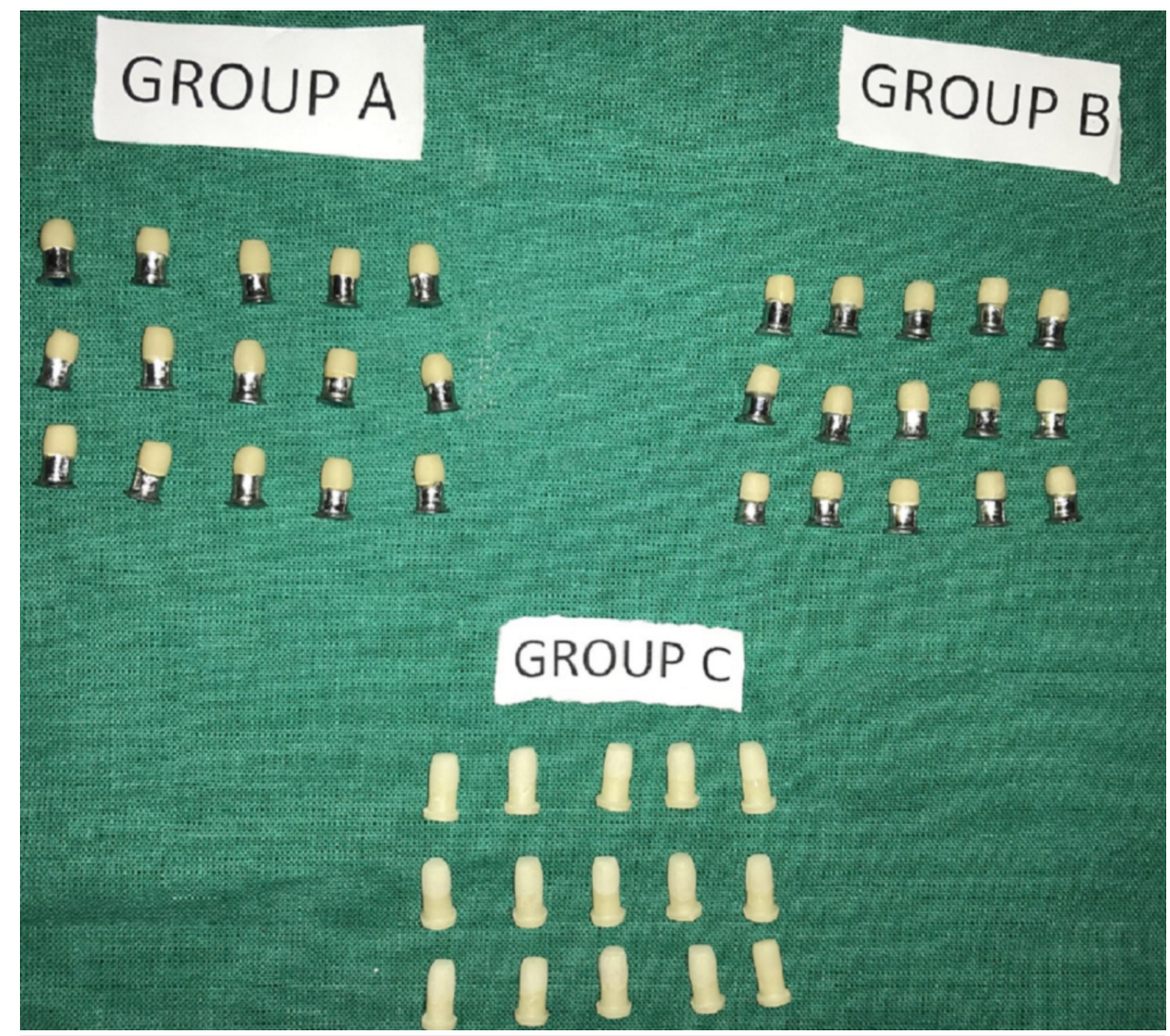

FIGURE 2: A) Ni-Cr B) Co-Cr C) Zirconium

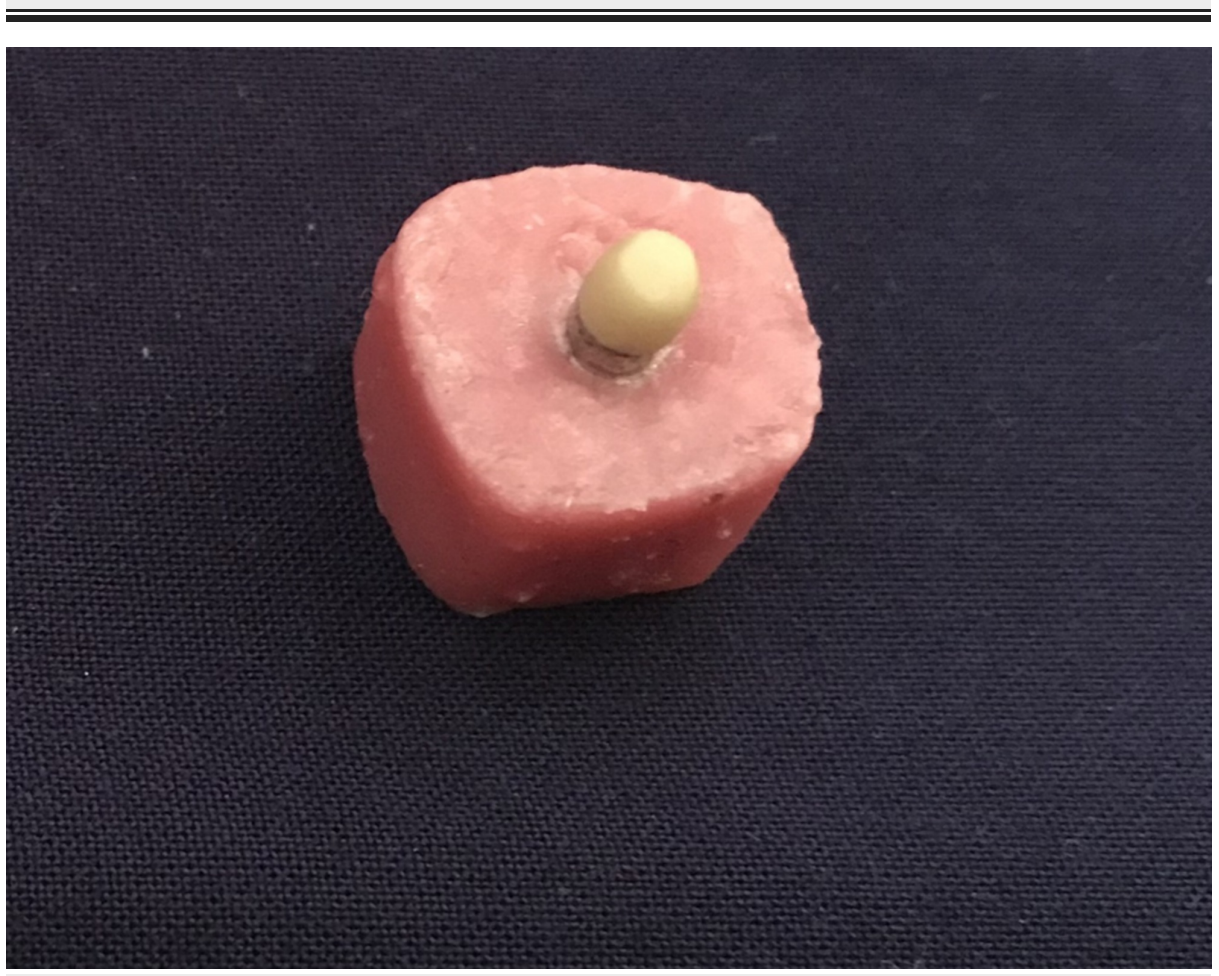

FIGURE 3: Specimen inserted in an acrylic block 


\section{Cureus}

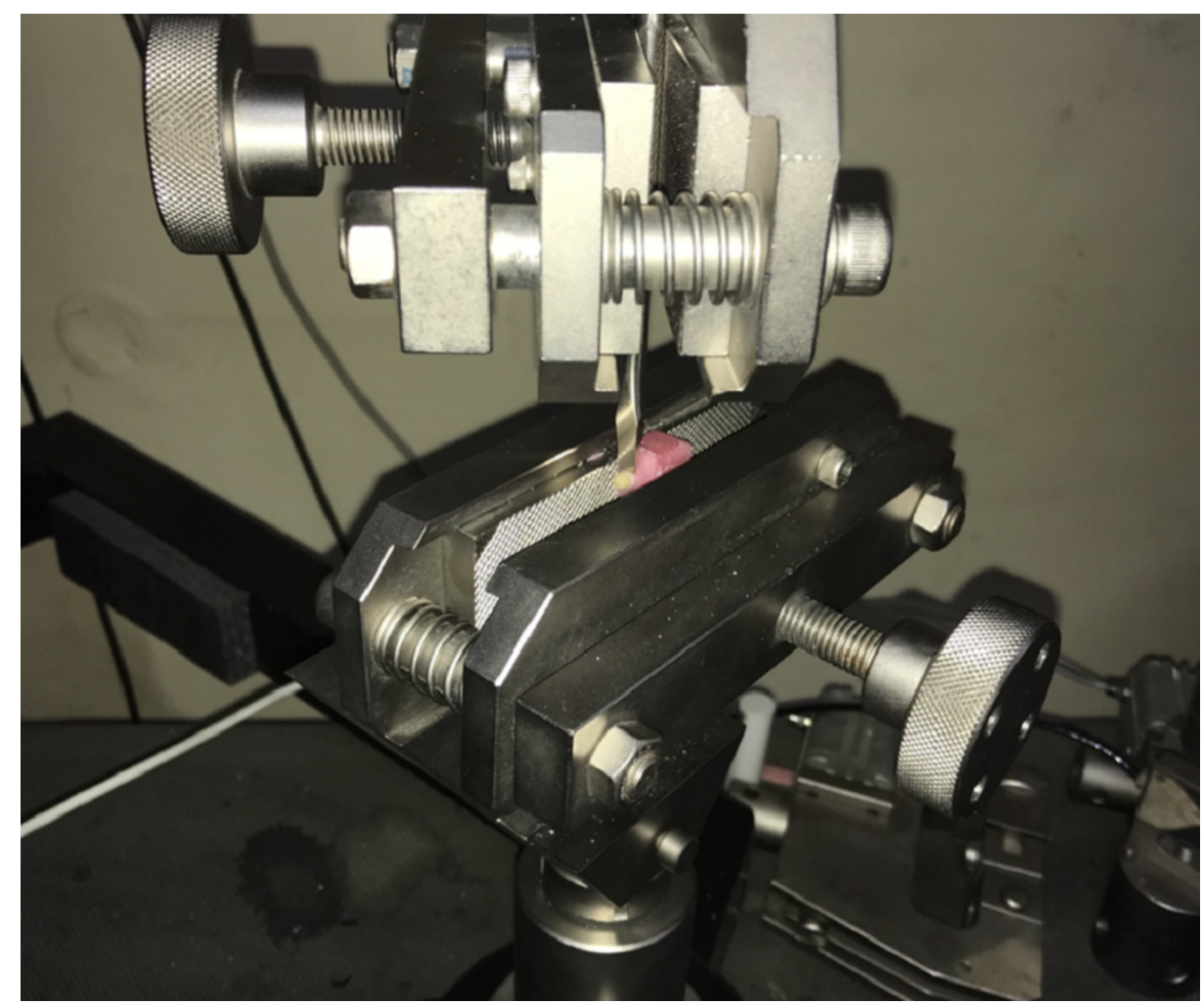

FIGURE 4: Placing the tool $1 \mathrm{~mm}$ above the junction

Dak Universal Testing Machine (UTM) Model 1500; Dak System Inc., Mumbai, India

Shear stress $(\mathrm{MPa})=\operatorname{Load}(\mathrm{N}) \div$ Area $(\mathrm{mm} 2)$

After a fracture, a scanning electron microscopy (SEM) analysis was performed to evaluate the nature of the fractured surfaces and determine whether these were adhesive or cohesive failures.

\section{Results}

The results obtained were statistically analyzed using a pairwise post-hoc test performed using the Tukey's test for multiple comparisons. The minimum, maximum, mean bond strength, and standard deviation of shear bond strength values between the three groups are given in Table 1 and Figure 5 . The mean shear bond strength and the standard deviation of ceramic bonded to $\mathrm{Ni}-\mathrm{Cr}, \mathrm{Co}-\mathrm{Cr}$, and zirconium are $35.55 \pm 4.64 \mathrm{M} \mathrm{Pa}$, $36.87 \pm 6.04 \mathrm{M} \mathrm{Pa}$, and $31.10 \pm 5.20 \mathrm{M} \mathrm{Pa}$, respectively. The above values indicate that $\mathrm{Ni}-\mathrm{Cr}$ and $\mathrm{Co}-\mathrm{Cr}$ bond strengths are nearly equal, whereas zirconium has a lower bond strength than the other two groups.

\begin{tabular}{|c|c|c|c|c|c|c|c|}
\hline \multirow{2}{*}{ Groups } & \multirow{2}{*}{ Min } & \multirow{2}{*}{ Max } & \multirow{2}{*}{ Mean } & \multirow{2}{*}{ SD } & \multirow{2}{*}{ SE } & \multicolumn{2}{|c|}{$95 \% \mathrm{Cl}$ for Mean } \\
\hline & & & & & & Lower Bound & Upper Bound \\
\hline Group A & 29.46 & 43.01 & 35.55 & 4.64 & 1.20 & 32.98 & 38.12 \\
\hline Group B & 26.66 & 46.39 & 36.87 & 6.04 & 1.56 & 33.52 & 40.22 \\
\hline Group C & 21.19 & 39.25 & 31.10 & 5.20 & 1.34 & 28.23 & 33.98 \\
\hline
\end{tabular}

TABLE 1: Summary of shear bond strength in three study groups (A, B, C) 


\section{Cureus}

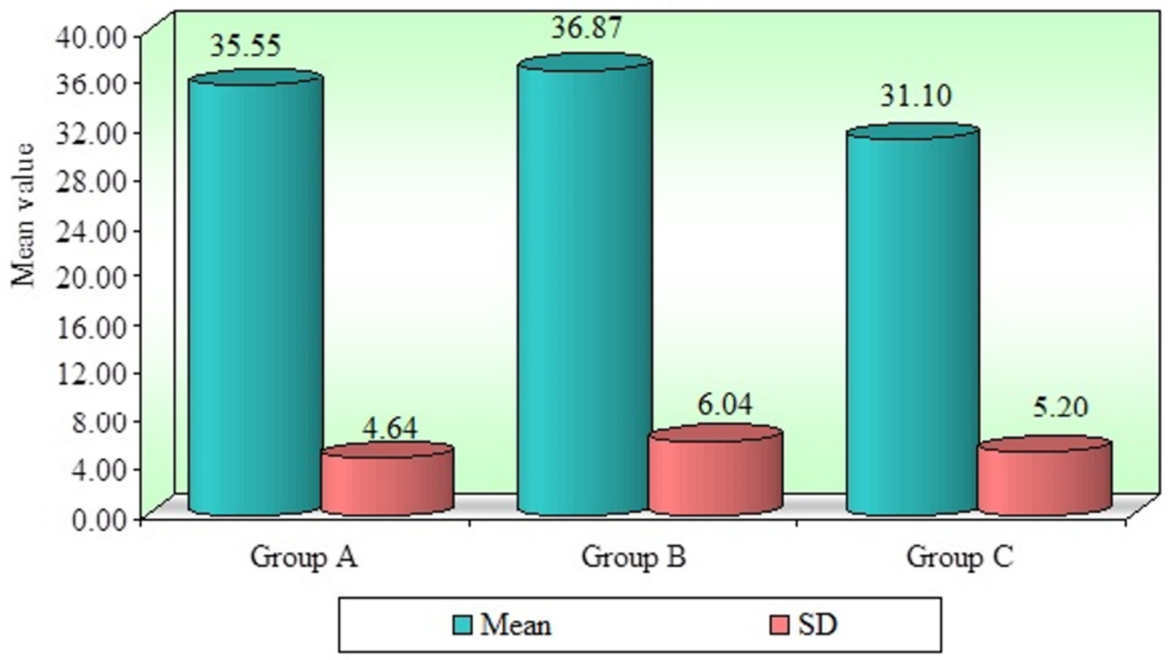

FIGURE 5: Comparison of the mean shear bond strength in the three study groups $(A, B, C)$

Tuckey's test for post-hoc significant differences between the $\mathrm{Ni}-\mathrm{Cr}$ and $\mathrm{Co}$ - $\mathrm{Cr}$ alloys was greater than .05 $(\mathrm{P}=.7770)$, indicating no significant difference. A comparison between $\mathrm{Ni}-\mathrm{Cr}$ and zirconium was also greater than $.05(\mathrm{P}=.069)$, indicating no significant difference. For the difference between $\mathrm{Co}-\mathrm{Cr}$ and zirconium, a value below .05 was found $(\mathrm{P}=.01)$, indicating a significant difference (Table 2). The results of the SEM analysis revealed that the majority of the failures that occurred (80\%) were of a mixed type (cohesive and adhesive) in Ni-Cr (Figure 6), Co-Cr (Figure 7), and zirconium (Figure 8). An SEM image of the base metal alloys and the zirconium group under high magnification (original magnification X250) showed many small pores in the veneering porcelain from which the fractures originated and propagated into the veneering ceramics. A careful examination found a thin layer of veneering porcelain covering the fracture surface.

\begin{tabular}{|c|c|c|c|c|c|c|}
\hline \multirow{2}{*}{ (I) Groups vs } & \multirow{2}{*}{ (J) Group } & \multirow{2}{*}{ Mean Difference (I-J) } & \multirow{2}{*}{ SE } & \multirow{2}{*}{ P-value } & \multicolumn{2}{|l|}{$95 \% \mathrm{Cl}$} \\
\hline & & & & & Lower Bound & Upper Bound \\
\hline Group A vs & Group B & -1.32 & 1.94 & 0.7770 & -6.04 & 3.41 \\
\hline Group A vs & Group C & 4.44 & 1.94 & 0.0690 & -0.28 & 9.17 \\
\hline Group B vs & Group C & 5.76 & 1.94 & $0.0140^{*}$ & 1.04 & 10.49 \\
\hline
\end{tabular}

TABLE 2: Pair-wise comparison of three study groups (A, B, C) with mean shear bond strength by Tuckey's multiple post-hoc procedures 


\section{Cureus}

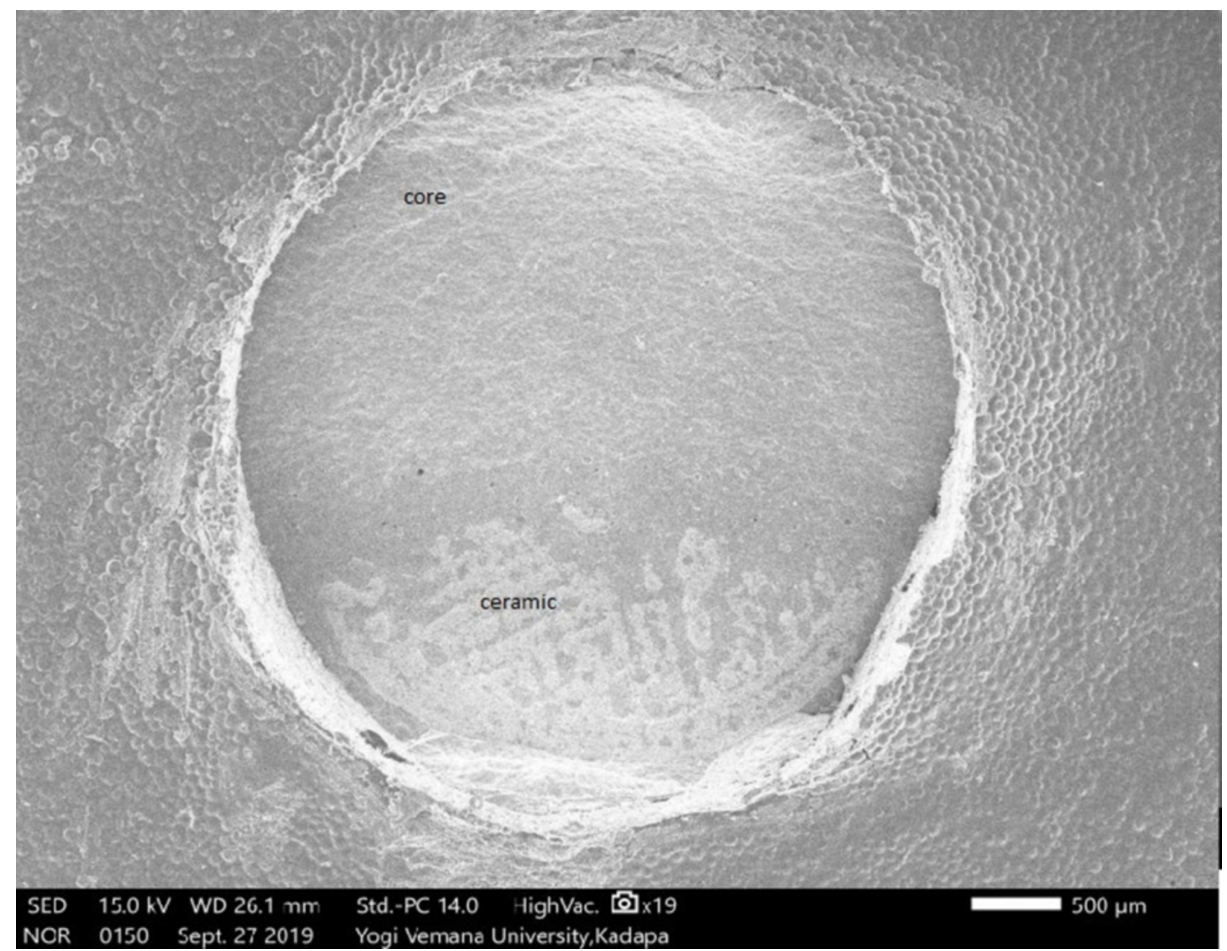

FIGURE 6: Scanning electron microscope (SEM) analysis of $\mathrm{Ni}-\mathrm{Cr}$ fractured surface showing mixed failure

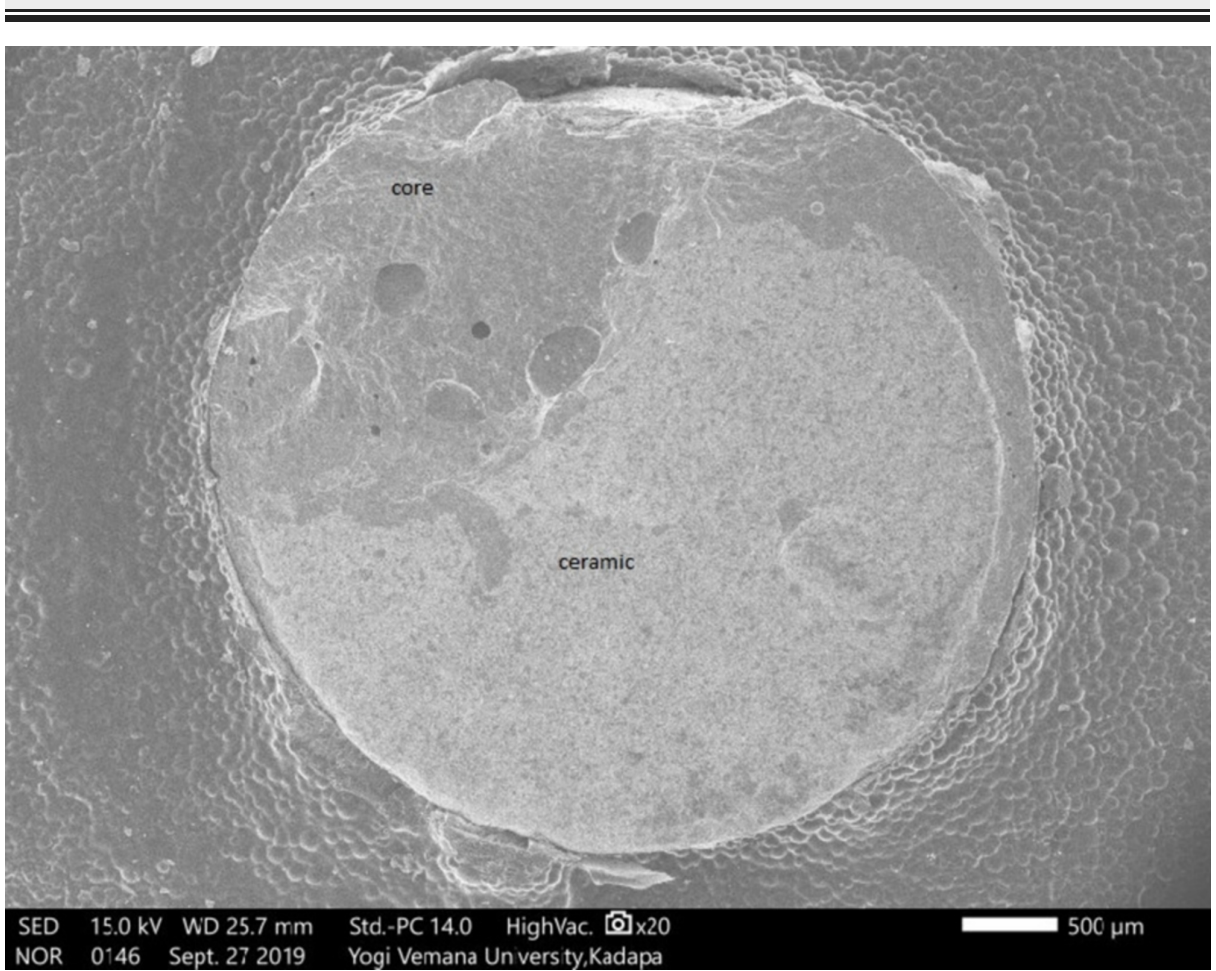

FIGURE 7: Scanning electron microscope (SEM) analysis of Co-Cr fractured surface showing mixed failure 


\section{Cureus}

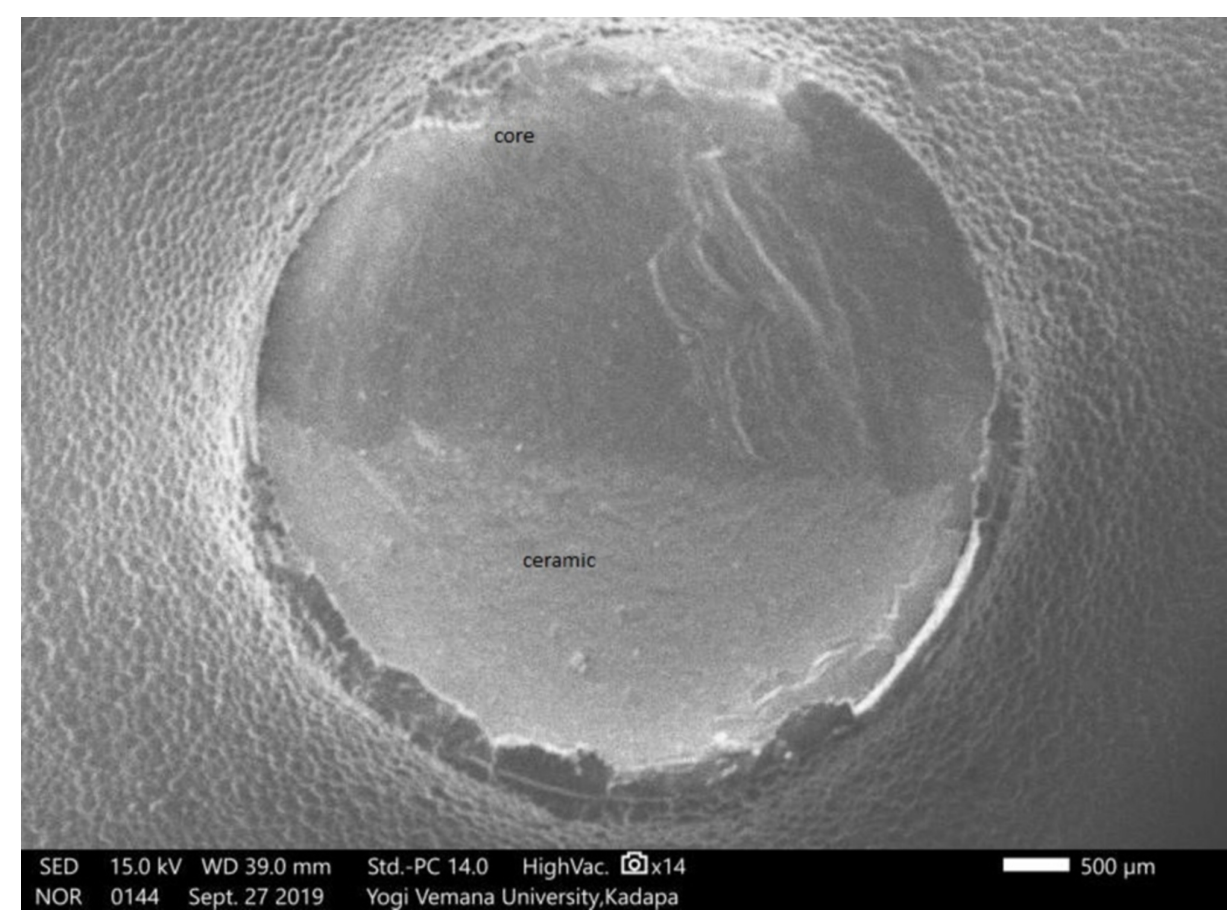

\section{FIGURE 8: Scanning electron microscope (SEM) analysis of zirconium fractured surface showing mixed failure}

\section{Discussion}

The bond strength measurement of the metal-ceramic system was standardized using the Shewickerath crack initiation test (three points bending test). To meet the ISO requirements, the mean de-bonding strength/crack initiation strength should be greater than $25 \mathrm{M} \mathrm{Pa}$ for the metal-ceramic system [2,17-18]. In this study, the shear bond strength test method was selected because of its simplicity and high reliability.

In previous studies, Dundar et al. [19] reported a shear bond strength in the range of $23-41 \mathrm{M} \mathrm{Pa}$, and AlDohan reported shear bond strength in the range of 22-31 M Pa for commercially available core-veneer allceramic systems (zirconium). In this study, the shear bond strength (SBS) value of veneering ceramic to a zirconium core was $31.10 \mathrm{M} \mathrm{Pa}$, confirming the finding of previous studies. However, unlike in the Al-Dohan study [20], our study results indicate a significant difference in mean SBS value between the zirconium group and the metal group. This difference in findings could be attributed to many factors, such as study design, methodology, skill, experience with the apparatus, and different properties of different materials. Some evaluations revealed that the fracture originated in the veneering porcelain in both the zirconium and metal-ceramic groups. The failure modes from the metal-ceramic and zirconium groups suggest the importance of the mechanical properties of veneering porcelain, as cracks initiated in the veneering porcelain. It is possible that internal defects of the veneer led to the initiation of fracture; thus, the fabrication techniques, such as layering, firing, surface finishing, and polishing of veneering porcelain, are critical [21]. Besides, the strength of the veneering porcelain is also related to the degree of crystallinity, paramount to the longevity of the restorations [22]. This study was performed in a dry environment without the influence of saliva, temperature, and $\mathrm{pH}$ changes [23]. Therefore, thermocycling or artificial aging procedures should be included in subsequent studies.

\section{Conclusions}

Within the limitations of this study, we concluded that the metal-ceramic group had more shear bond strength than zirconium, and both metal-ceramic groups have similar strength. The SEM analysis indicated that the three groups have combined failure modes that originated in the veneering porcelain in both the zirconium and metal groups. The fracture origin in the veneering porcelain was mostly on the loaded surface. However, more studies have to be done by using an ample number of samples. In addition, the samples should be subjected to the tests in the clinical scenario to provide more reliability and accuracy.

\section{Additional Information}

\section{Disclosures}

Human subjects: All authors have confirmed that this study did not involve human participants or tissue. Animal subjects: All authors have confirmed that this study did not involve animal subjects or tissue. 
Conflicts of interest: In compliance with the ICMJE uniform disclosure form, all authors declare the following: Payment/services info: All authors have declared that no financial support was received from any organization for the submitted work. Financial relationships: All authors have declared that they have no financial relationships at present or within the previous three years with any organizations that might have an interest in the submitted work. Other relationships: All authors have declared that there are no other relationships or activities that could appear to have influenced the submitted work.

\section{References}

1. Pjetursson BE, Tan K, Lang NP, Brägger U, Egger M, Zwahlen M: A systematic review of the survival and complication rates of fixed partial dentures (FPDs) after an observation period of at least 5 years. Clin Oral Implants Res. 2004 Dec, 15:667-676. 10.1111/j.1600-0501.2004.01117.x

2. Choi BK, Han JS, Yang JH, Lee JB, Kim SH: Shear bond strength of veneering porcelain to zirconia and metal cores. J Adv Prosthodont. 2009, 1:129-135. 10.4047/jap.2009.1.3.129

3. Wataha JC, Messer RL: Casting alloys. Dent Clin North Am. 2004, 48:499-512. 10.1016/j.cden.2003.12.010

4. Wataha JC: Alloys for prosthodontic restorations. J Prosthet Dent. 2002 Apr, 87:351-63. 10.106 7/mpr.2002.123817

5. Roach M: Base metal alloys used for dental restorations and implants . Dent Clin North Am. 2007, 51:603627.

6. Lee DH, Lee BJ, Kim SH, Lee KB: Shear bond strength of porcelain to a new millable alloy and a conventional castable alloy. J Prosthet Dent. 2015, 113:329-335. 10.1016/j.prosdent.2014.09.016

7. de Melo RM, Travassos AC, Neisser MP: Shear bond strengths of a ceramic system to alternative metal alloys. J Prosthet Dent. 2005, 93:64-69. 10.1016/j.prosdent.2004.10.017

8. Joias RM, Tango RN, Junho de Araujo JE, Junho de Araujo MA, Ferreira Anzaloni Saavedra Gde S, Paes-Junior TJ, Kimpara ET: Shear bond strength of a ceramic to Co-Cr alloys . J Prosthet Dent. 2008, 99:54-59. 10.1016/S0022-3913(08)60009-8

9. Galo R, Frizzas DG, Rodrigues RC, Ribeiro RF, de Mattos MD: Surface treatment on the shear bond strength of dental ceramics to titanium commercially pure. European J Gen Dent. 2017, 6:77-81.

10. Raigrodski AJ: Contemporary materials and technologies for all ceramic fixed partial dentures: a review of the literature. J Prosthet Dent. 2004, 92:557-562. 10.1016/j.prosdent.2004.09.015

11. Tinschert J, Natt G, Mohrbotter N, Spiekermann H, Schulze KA: Lifetime of alumina-and zirconia ceramics used for crown and bridge restorations. J Biomed Mater Res B Appl Biomater. 2007, 80:317-321. 10.1002/jbm.b.30599

12. Sailer I, Strasding M, Valente NA, Zwahlen M, Liu S, Pjetursson BE: A systematic review of the survival and complication rates of zirconia-ceramic and metal-ceramic multiple-unit fixed dental prostheses. Clin Oral Implants Res. 2018, 29:184-198. 10.1111/clr.13277

13. Sailer I, Fehér A, Filser F, Lüthy H, Gauckler LJ, Schärer P, Franz Hämmerle CH: Prospective clinical study of zirconia posterior fixed partial dentures: 3-year follow-up. Quintessence Int. 2006, 37:685-693.

14. Raigrodski AJ, Chiche GJ, Potiket N, Hochstedler JL, Mohamed SE, Billiot S, Mercante DE: The efficacy of posterior three-unit zirconium-oxide-based ceramic fixed partial dental prostheses: a prospective clinical pilot study. J Prosthet Dent. 2006, 96:237-244. 10.1016/j.prosdent.2006.08.010

15. Guazzato M, Proos K, Quach L, Swain MV: Strength, reliability and mode of fracture of bilayered porcelain/zirconia (Y-TZP) dental ceramics. Biomaterials. 2004 Sep, 25:5045-5052. 10.1016/j.biomaterials.2004.02.036

16. Deepak K, Ahila SC, Muthukumar B, Vasanthkumar M: Comparative evaluation of effect of laser on shear bond strength of ceramic bonded with two base metal alloys: an in-vitro study. Indian J Dent Res. 2013, 24:610-615. 10.4103/0970-9290.123396

17. ISO 9693:2019. Dentistry - compatibility testing for metal-ceramic and ceramic-ceramic systems . (2019). https://www.iso.org/standard/75855.html.

18. Albakry M, Guazzato M, Swain MV: Fracture toughness and hardness evaluation of three pressable allceramic dental materials. J Dent. 2003, 31:181-188. 10.1016/s0300-5712(03)00025-3

19. Dündar M, Ozcan M, Cömlekoglu E, Güngör MA, Artunç C: Bond strengths of veneering ceramics to reinforced ceramic core materials. Int J Prosthodont. 2005, 18:71-72.

20. Al-Dohan HM, Yaman P, Dennison JB, Razzoog ME, Lang BR: Shear strength of core-veneer interface in bilayered ceramics. J Prosthet Dent. 2004, 91:349-355. 10.1016/j.prosdent.2004.02.009

21. Kelly JR, Campbell SD, Bowen HK: Fracture-surface analysis of dental ceramics. J Prosthet Dent. 1989, 62:536-541. 10.1016/0022-3913(89)90075-9

22. Quinn JB, Sundar V, Lloyd IK: Influence of microstructure and chemistry on the fracture toughness of dental ceramics. Dent Mater. 2003, 19:603-611. 10.1016/S0109-5641(03)00002-2

23. Sobrinho LC, Glover RH, Knowles JC, Cattell MJ: Comparision of the wet and dry fatigue properties of all ceramic crowns. J Mater Sci Mater Med. 1998, 9:517-521. 10.1023/a:1008887805177 